OPEN ACCESS

Citation: Propa Joy R. Santor, Duane Dominic B. Santiago, Conrado Joshua V. Mataga, Elyjha S. Gabriel, GrecebioJonathan D. Alejandro (2021) Hedyotis hamiguitanensis (Rubiaceae: Spermacoceae), a new species from Mt. Hamiguitan, Davao Oriental, Philippines and its systematic position in Hedyotis. Webbia. Journal of Plant Taxonomyand Geography76(2): 195-202. doi: 10.36253/jopt-10651

Received: March 14, 2021

Accepted: June 24, 2021

Published: September 7, 2021

Copyright: (c) 2021 Propa Joy R. Santor, Duane Dominic B. Santiago, Conrado Joshua V. Mataga, Elyjha S. Gabriel, Grecebio Jonathan D. Alejandro. This is an open access, peer-reviewed article published by Firenze University Press (http://www.fupress.com/webbia) and distributed under the terms of the Creative Commons Attribution License, which permits unrestricted use, distribution, and reproduction in any medium, provided the original author and source are credited.

Data Availability Statement: All relevant data are within the paper and its Supporting Information files.

Competing Interests: The Author(s) declare(s) no conflict of interest.

Editor: Lia Pignotti

ORCID

PJRS: https://orcid.org/0000-00028414-9018

GJDA: https://orcid.org/0000-00034524-0385

\section{Hedyotis hamiguitanensis (Rubiaceae: Spermacoceae), a new species from Mt. Hamiguitan, Davao Oriental, Philippines and its systematic position in Hedyotis}

\author{
Propa Joy R. Santor ${ }^{2,3, *}$, Duane Dominic B. Santiago ${ }^{2}$, Conrado Joshua \\ V. Mataga ${ }^{2}$, Elyjha S. Gabriel ${ }^{2}$, Grecebio Jonathan D. Alejandro ${ }^{1,2,3}$ \\ ${ }^{1}$ The Graduate School, University of Santo Tomas, España Boulevard, 1015 Manila, Phil- \\ ippines \\ ${ }^{2}$ College of Science, University of Santo Tomas, España Boulevard, 1015 Manila, Philippines \\ ${ }^{3}$ Research Centre for the Natural and Applied Sciences, University of Santo Tomas, \\ España Boulevard, 1015 Manila, Philippines \\ *Corresponding author. E-mail: prsantor@ust.edu.ph; propa.santor@gmail.com
}

\begin{abstract}
Hedyotis hamiguitanensis, from Mt. Hamiguitan, Davao Oriental, Philippines, is described, illustrated, and compared with two similar species, $H$. whiteheadii and $H$. schlechteri. This species is distinguished from congeneric Philippine species by its $5-12$ $\mathrm{cm}$ long, compound, umbellate inflorescences, pendulous flowers, lanceolate to oblanceolate, thick, scabrid leaf blades with revolute margins. Its phylogenetic systematic position within the tribe Spermococeae is determined with a phylogenetic analysis using chloroplast (rps16, petD) and nuclear ribosomal (ITS, ETS) nucleotide sequence data.
\end{abstract}

Keywords: Hedyotis, Rubiaceae, Philippines, taxonomy.

\section{INTRODUCTION}

Hedyotis Linnaeus (1753: 101) is part of the Hedyotis-Oldenlandia complex, a taxonomically confusing group that was formerly placed in the tribe Hedyotideae, which is now part of tribe Spermacoceae (Bremer 1996; Andersson and Rova 1999; Bremer and Manen 2000). The genus has long been controversial because of the lack of taxonomic delimitation and molecular data (Terrell and Robinson 2003). Recent phylogenetic analyses based on nuclear and plastid sequences of Asian-Pacific taxa from this group have identified 13 well-supported monophyletic genera (Neupane et al., 2015). Diagnostic characters such as habit, fruit type, seed form, and pollen type were compared to the phylogeny for characterizing the clades (Kårehed et al 2008; Groeninckx et al. 2009; Guo et al. B 2013; Wikström et al. 2013; Neupane et al. 2015). In the latest revision (Neupane et al. 2015), members of Hedyotis s.str. included species from Sri Lanka, India, SE China, Indo-Chi- 
na, Malesia, Papuasia, Northwest Pacific, and Australia. The recent studies lack Hedyotis species occurring in the Philippines. Hedyotis is characterized by its habit -suffrutescent herbs, shrubs, or small trees -, its capsules with apex not protruding beyond the calyx lobes, the septicidal dehiscence usually followed by a partial apical loculicidal dehiscence that sometimes results in two semi-split valves and, the dorsiventrally compressed seeds (Wikström et al. 2013). The flowers have a pubescent corolla tube and pollen with 3-4 ecto-apertures, endoapertures shaped as an endocingulum and a tectum with a double reticulum pattern (Neupane et al. 2015). There are approximately 180 species in Hedyotis (Neupane et al. 2015), 36 of which occur in the Philippines (Pelser et al. 2011).

During fieldwork of the Thomasian Angiosperm Phylogeny and Barcoding Group (TAPBG) on Mt. Hamiguitan, Davao Oriental, Philippines, an interesting taxon was discovered. Two populations were observed, one in mossy forests and the other in pygmy forests on the same mountain. The collected material is morphologically similar to Hedyotis whiteheadii Merrill (1907: 303) and $H$. schlechteri Merrill \& Perry (1945: 1), but detailed comparison showed that these two species differ from the newly collected material by their vegetative and inflorescence morphology. Therefore, a new Hedyotis species is here described and illustrated. We also included the new species in a maximum likelihood and Bayesian phylogenetic analysis of Hedyotis s.str. (sensu Neupane et al. 2015) based on chloroplast (rps16, petD) and nuclear ribosomal (ITS, ETS) nucleotide sequence data to elucidate its position within the genus.

\section{MATERIAL AND METHODS}

Hedyotis specimens were collected in the forests of Mt. Hamiguitan, Davao Oriental, Philippines, on 15 April 2017. Measurements, colors and other details given in the descriptions are based on field observations, herbarium specimens and reproductive parts preserved in $70 \%$ ethanol. Microscopic features were analyzed using a dissecting microscope (Olympus SZ2-ILST). Measurements were obtained using a metric vernier caliper. Character state terminology is based on Beentje (2010). Hedyotis specimens from different herbaria (A, CAHUP, K, PNH, PUH US, and USTH) were compared to our specimens. Additional specimens were examined on JSTOR Global Plants (https://plants.jstor. org/, accessed 18 May 2021). Herbarium specimens were deposited in USTH.

For the molecular data, DNA was extracted from silica gel-dried leaves using the DNeasy Plant Mini Kit
(Qiagen, Germany) following the manufacturer's protocol. The amplification protocol for nuclear and chloroplast regions follows Kårehed et al. (2008: 845) and Groeninckx et al. (2009: 111), respectively. The alignment file was downloaded from the supplementary data provided by Neupane et al. (2015). A total of 293 accessions were analyzed with the addition of 2 samples from this study, H. hamiguitanensis CB177051 and CB17036. The new sequences from plastid (rps16, petD) and nuclear (ITS) regions of $\mathrm{H}$. hamiguitanensis produced during our investigation were deposited in Genbank (Genbank accession numbers MZ407950, MZ435801, MZ435799 for USTH016306 MZ407951, MZ435802, MZ435800 for USTH016305 respectively) Sequences were edited and pre-aligned using CodonCode Aligner v.4.0.4 (CodonCode Corporation, Dedham, MA) and subsequently aligned using MAFFT v.7 (Katoh and Standley, 2013). The alignment was manually adjusted using SeaView Sequence Aligner V.4 (Guoy et al., 2010). ML tree search was performed in RaxML-HPC Blackbox v. 8.2.12. while Bayesian inference was performed using MrBayes v.3.2 (Ronquist et al. 2012) with 15 million MCMC iterations. Mrbayes and RaxML searches were conducted on the CIPRES Portal (Miller et al. 2010).

\section{TAXONOMY}

Hedyotis hamiguitanensis Santor, Santiago \& Alejandro, sp. nov. (Figures 1, 2).

Type: Philippines, Davao Oriental, Pygmy forest in Mt. Hamiguitan, $16.7400^{\circ} \mathrm{N}, 1600 \mathrm{~m}, 126.1817^{\circ} \mathrm{E}, 15 \mathrm{Apr}$ 2017, Ordas, Alfeche \& Zamudio CB17051 (holotype, Accession numbers from USTH:USTH016306.1; isotypes: USTH016306.2, USTH016306.3).

\section{Diagnosis}

Hedyotis hamiguitanensis is similar to $H$. whiteheadii and $H$. schlechteri because of general leaf size ranging from $1.5-4 \mathrm{~cm}$ with 3-4 lateral nerves, densely hirsute petioles, and compound peduncled inflorescence, from which it can be distinguished by its lanceolate to oblanceolate, relatively thick leaves, scabrid surface, margins that are entire and revolute, stems, stipules, peduncle, pedicels with hirsute indumentum, inflorescence a compound, 5-12 cm long, umbel, and by the pendulous, 8-11 mm long flowers.

\section{Description}

Shrub $0.5-2 \mathrm{~m}$ tall. Stems terete, about $1-2 \mathrm{~mm}$ in diameter, olive green with maroon coloration on some 


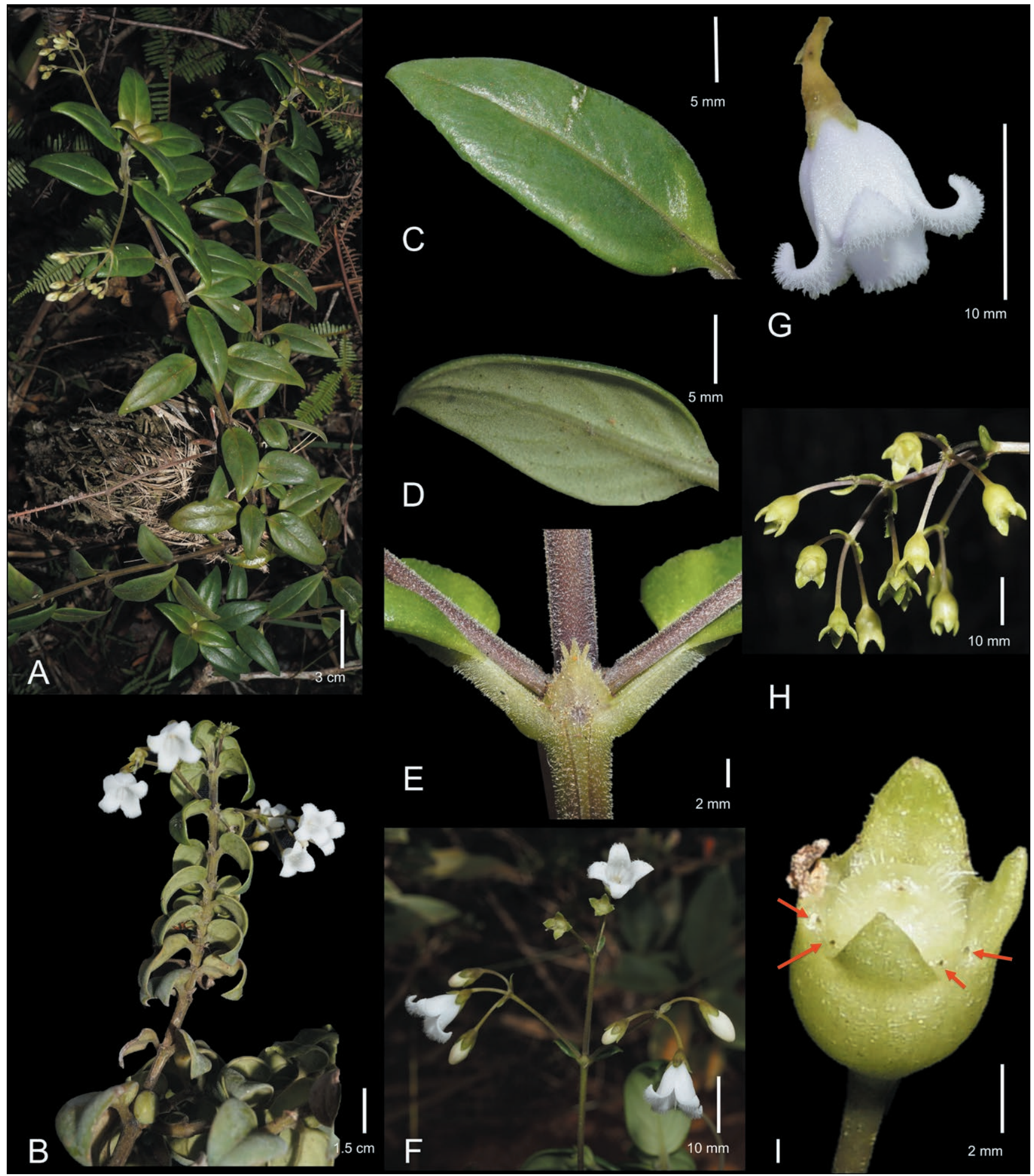

Figure 1. Hedyotis hamiguitanensis. A. Habit of CB17051 found in mossy forest at $1000 \mathrm{~m}$ elevation. B. Habit of CB17036 found in the pygmy forest of Mt. Hamiguitan at 1600 m elevation. C. Leaf adaxial surface. D. Leaf abaxial surface. E. Node, showing intrapetiolar stipule with laciniate teeth; stems, stipules and petioles are hirsute. G. Flower. H. Infructescence. I. Fruit with 2 colleters at each calyx lobe sinus. Photos by N.K. Alfeche. 


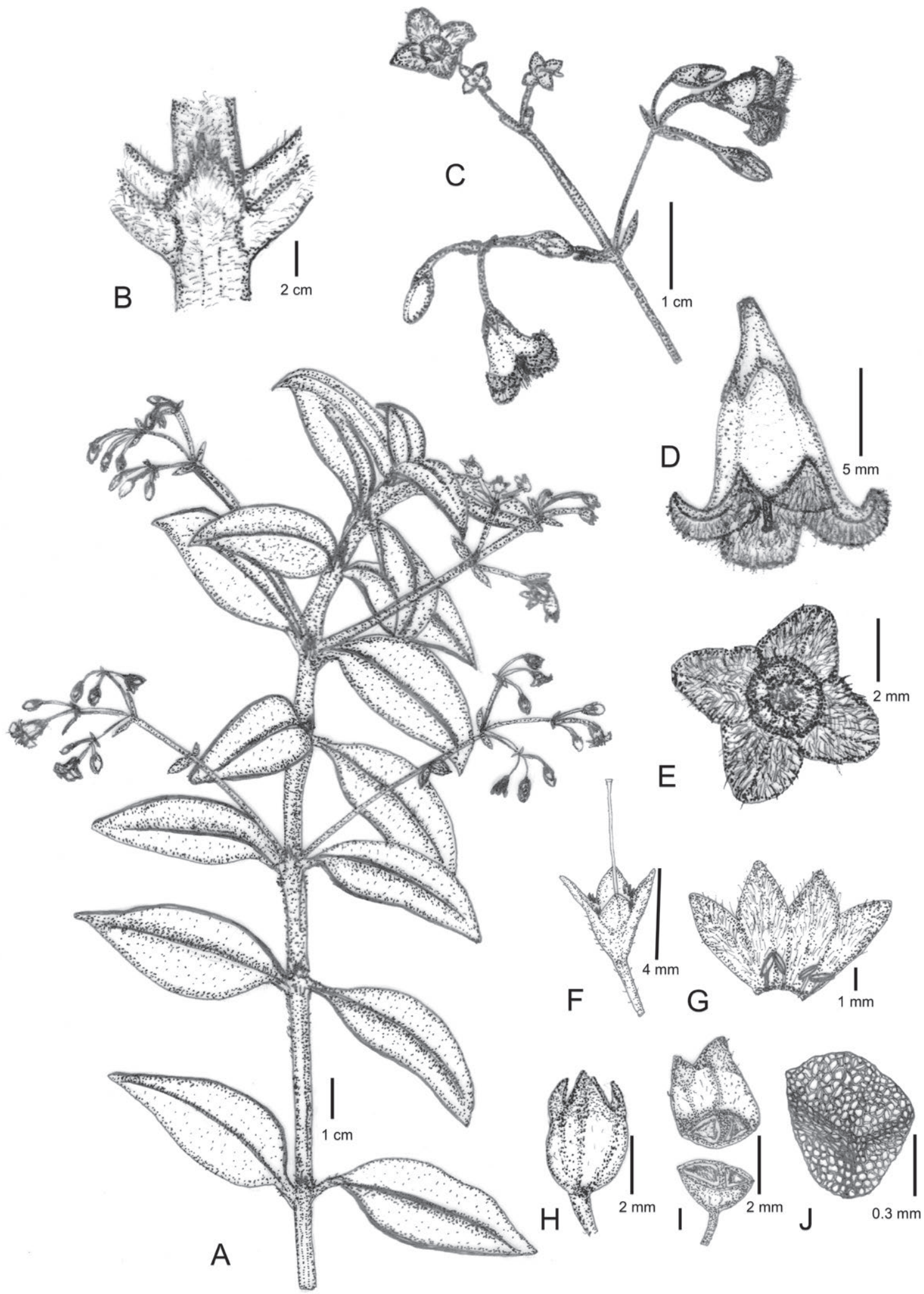

Figure 2. Hedyotis hamiguitanensis. A. Flowering and fruiting branch. B. Stipules. C. Inflorescence. D. Flower, lateral view. E. Flower, top view. F. Calyx and style. G. Opened Corolla showing stamens. H. Capsule. I. Dissected capsule showing the 2 locules. J. Seed. Illustrated by P.J.R. Santor. 
parts, densely hirsute; internodes $1-5 \mathrm{~cm}$ long; branchlets sulcate, $1-2 \mathrm{~mm}$ in diameter. Stipules interpetiolar, triangular ovate, $2-4 \times 3-4 \mathrm{~mm}$, with 9-11 lacinia, hirsute. Leaves with petioles 1-5 mm long, subsessile in populations above $1600 \mathrm{~m}$ elevation, densely hirsute; blades lanceolate to broadly ovate, $1.5-3 \times 0.8-1.5 \mathrm{~cm}$, thinner leaves with margins recurved, thicker leaves with entire lamina recurved from the midrib; lamina scabrid on both surfaces, abaxial surface may appear densely hirsute on younger leaves, coriaceous, yellowgreen to green on the adaxial surface, abaxial surface pale green when fresh, olive green to dark brown and brittle when dry, base subcordate to obtuse, apex attenuate to acute, lamina scabrid on both surfaces, abaxial surface may appear densely hirsute on younger leaves, thinner leaves with margins revolute; margins of thicker leaves revolute from the midrib; midrib distinct, canaliculate, sparsely to densely scabrid on the adaxial surface, sparsely scabrid on the abaxial surface; secondary veins 3 or 4 on each side of the midrib, obscure on thicker leaves, evident in thin leaves, tertiary venation not prominent. Inflorescence axillary, a compound umbel, $6-12 \mathrm{~cm}$ long in populations above $1000 \mathrm{~m}$ elevation, or $5-6.5 \mathrm{~cm}$ long in populations above $1600 \mathrm{~m}$ elevation, pendulous, hirsute; peduncle terete, $2-9 \mathrm{~cm}$ long, $0.2-0.5$ $\mathrm{mm}$ in diam., hirsute; bracts ovate to lanceolate, $3-6 \times$ 2-4 $\mathrm{mm}$, apex attenuate, scabrid on the adaxial surface, hirsute or with bullate configuration on the abaxial surface, margins flat or revolute. Inflorescence cymose, 3(4)-flowered, 1-3 cm long, 3-5 $\mathrm{mm}$ in diameter, sparsely hirsute to glabrous; bracteoles ovate to lanceolate, 2-3 $\times 0.5-1.5 \mathrm{~mm}$, apices acute. Pedicels terete, $10-30 \mathrm{~mm}$ long. Flowers 4-merous, pendulous, cupuliform, 8-11 $\mathrm{mm}$ long, white; . Calyx subcampanulate, 2-4 $\mathrm{mm}$ long, $3 \mathrm{~mm}$ in diameter; tube bell-shaped with constricted base, $1-1.5 \mathrm{~mm}$ long, sparsely hirsute to glabrous; lobes 1-2.5 mm long, apex attenuate, puberulous, 2-3 clavate indumentum located in the margin in between each calyx lobe. Corolla 6-11 mm long, glabrous, white; tube 4-6 mm long, pubescent inside; lobes lanceolate, 2-5 $\mathrm{mm}$ long, apex acute. Stamens 2.5-4.2 mm long, included, inserted at $2 \mathrm{~mm}$; filaments $1-2 \mathrm{~mm}$ long, glabrous; anthers oblong, 1-2 mm long, dorsifixed. Style 6-7 $\mathrm{mm}$ long, glabrous, exerted $1.5-2.5 \mathrm{~mm}$ beyond corolla mouth. Capsules urceolate to ovoid, 3-4 $32 \mathrm{~mm}$, septicidal; calyx lobes persistent, $1.5 \mathrm{~mm}$ long. Seeds numerous, angular, dorsiventrally compressed, $0.5-0.7 \mathrm{~mm}$ long, black.

\section{Etymology}

The specific epithet is based on the type locality, Mt. Hamiguitan, Davao Oriental, Philippines.

\section{Distribution and habitat}

This new species is currently known only from its type localities. Hedyotis hamiguitanensis occurs in the mossy forest of Mt. Hamiguitan at c. $1000 \mathrm{~m}$ elevation, and in pygmy forest on Mt. Hamiguitan at c. $1600 \mathrm{~m}$ elevation.

\section{Phenology}

Hedyotis hamiguitanensis was observed flowering and fruiting in April.

\section{Provisional IUCN Conservation assessment}

This species was only collected at the type localities. Although two populations were found, few individuals were observed in the mossy and pygmy forest. The distribution range of this species remains unknown. Thus, the conservation status of $H$. hamiguitanensis is Data Deficient (DD) based on the IUCN (2019) categories.

\section{Additional Specimens examined (paratypes)}

PHILIPPINES. Davao Oriental: Mossy forest in Mt. Hamiguitan, $6.7400^{\circ} \mathrm{N}, 1000 \mathrm{~m}, 126.1817^{\circ}$ E, 15 Apr 2017, Ordas, Alfeche \& Zamudio CB17036 (USTH016305.1, USTH016305.2, USTH016305.3).

\section{Phylogenetic Analysis}

The phylogenetic analysis (Fig. 3) based on the combined nuclear (ITS, ETS) and plastid (petD, rps16) data revealed that $H$. hamiguitanensis is embedded within the Hedyotis s str. clade (Neupane et al. 2015) and is sister to a clade consisting of $H$. schlechteri and $H$. valetoniana $(B S=90, B P P=0.97)$, both from New Guinea. Although the two populations observed CB17051 and CB17036 showed differences in leaf size and thickness (Figure $1 \mathrm{~A} \& \mathrm{~B}$ ), phylogenetic analysis revealed that both populations formed a monophyletic group ( $\mathrm{BS}=100, \mathrm{BPP}=1.00)$, supporting the view that these two populations belong to the same species and the morphological differences may be due to adaptation to environmental conditions (Fig. 3).

\section{Discussion}

Two samples representing Hedyotis hamiguitanensis Santor, Santiago \& Alejandro were collected and analyzed. Field sample CB17051 Ordas, Alfeche \& Zamudio was collected on the peak of Mt. Hamiguitan, Davao Oriental, at c. $1600 \mathrm{~m}$ elevation, while CB17036 Ordas, Alfeche \& Zamudio was collected in the mossy forest at c. $1000 \mathrm{~m}$ elevation. The two collections have similar morphology in their vegetative and floral characters, but were different in terms of size, including plant height, leaf 


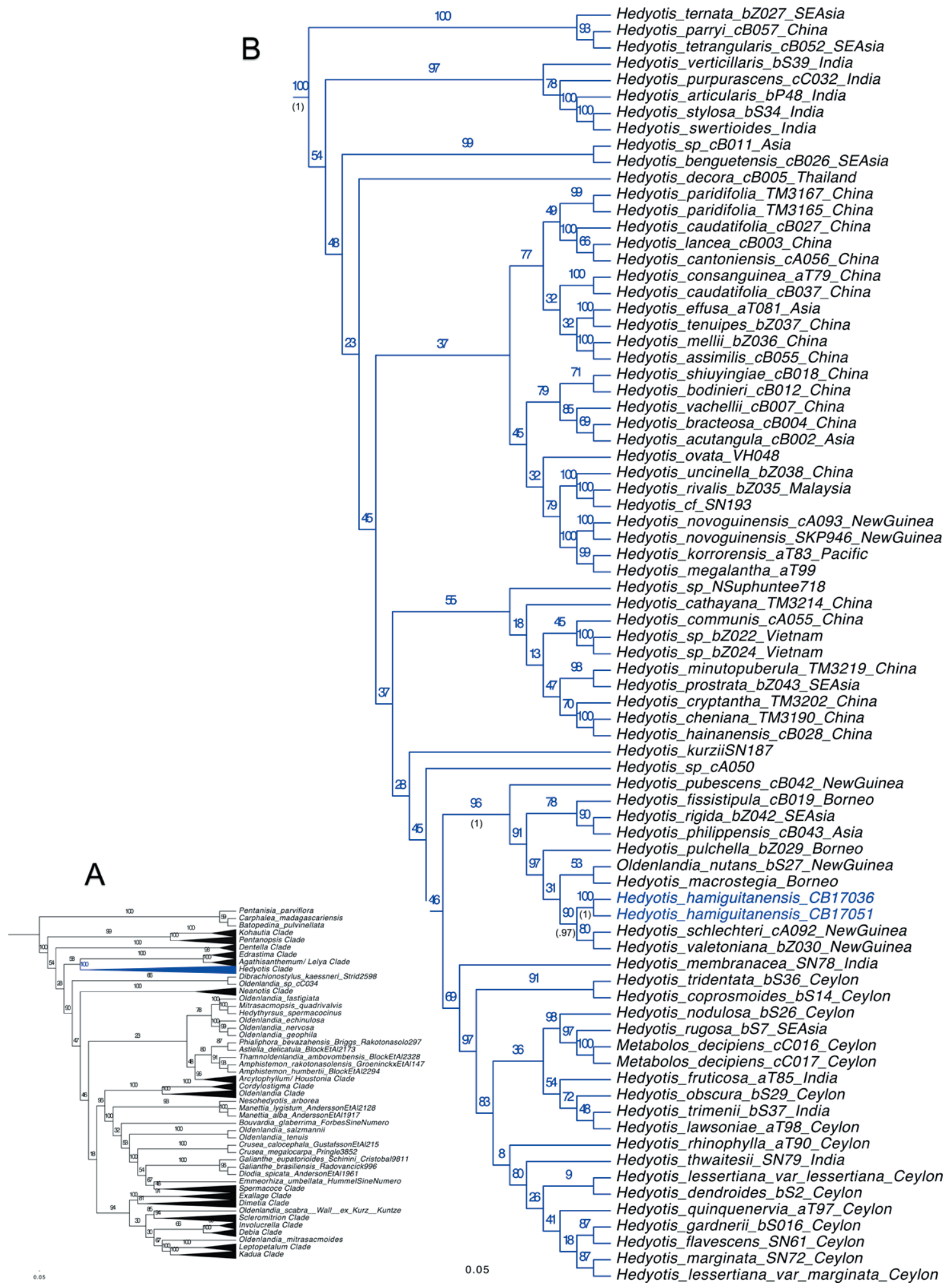

Figure 3. ML tree showing phylogenetic relationships in the genus Hedyotis using the combined nuclear (ITS, ETS) and plastid (petD, rps16) data of Neupane et al. (2015) and the two gatherings of Hedyotis hamiguitanensis. Values above the nodes represent bootstrap support (BS) while values in parenthesis are Bayesian Posterior Probabilities (BPP). The field collection number after the taxon indicates different populations or individuals. A. Shows the collapsed tree with the established major clades (collapsed). B. Phylogenetic relationships in the Hedyotis clade. 
Table 1. Comparative morphology between H. hamiguitanensis (CB177051, CB17036), H. whiteheadii and H. schlechteri

\begin{tabular}{|c|c|c|c|}
\hline Characters & H. hamiguitanensis & H. whitehedii & H. schlechteri \\
\hline \multicolumn{4}{|l|}{ Leaf } \\
\hline shape & lanceolate to oblanceolate & broadly ovate & broadly ovate \\
\hline length $(\mathrm{cm})$ & $1.5-3$ & $1.5-3$ & $2-4$ \\
\hline width $(\mathrm{cm})$ & $0.8-1.5$ & $1-1.8$ & $1-1.5$ \\
\hline surface & adaxial: scabrid abaxial: scabrid/hirsute & glabrous on both surfaces & scabrid on both surfaces \\
\hline lateral veins & obsolete & obscure & prominent \\
\hline margin & revolute & revolute & planar \\
\hline \multicolumn{4}{|l|}{ Petiole } \\
\hline length $(\mathrm{mm})$ & $(0-)$ 1-5 & $1.5-2$ & 5 \\
\hline \multicolumn{4}{|l|}{ Stipules } \\
\hline surface & hirsute & hirsute & scabrid \\
\hline \multicolumn{4}{|l|}{ Inflorescence } \\
\hline type & compound umbel & compound cyme & compound cyme \\
\hline length $(\mathrm{cm})$ & $5-12$ & $2-3$ & $5-6.5$ \\
\hline \multicolumn{4}{|l|}{ Flowers } \\
\hline direction & pendulous & erect & erect \\
\hline flower length (mm) & $8-11$ & $5-6$ & $5-7$ \\
\hline Adaxial corolla lobe surface & hirsute & hirsute & glabrous \\
\hline
\end{tabular}

dimensions, degree of curvature of the leaf blade margins, petiole length, inflorescence length, and flower size. The size differences of the two samples can be attributed to different environmental conditions - elevation, amount of sunlight and availability of nutrients in the soil.

Hedyotis hamiguitanensis shares features with the allied species $H$. whiteheadii, notably the leaf blade $1.5-3$ $\times 0.8-1.5 \mathrm{~cm}$, the lamina thickness, the obscure lateral veins, revolute margins, and the hirsute stipules. However, H. hamiguitanensis found at c. $1000 \mathrm{~m}$. altitude differs from $H$. whiteheadii in its lanceolate to oblanceolate leaves (vs. broadly ovate), scabrid leaf surfaces (vs. glabrous), compound umbels 5-12 cm long (vs. compound cymes 2-3 cm long), and significantly larger flowers 8-11 mm (vs. 5-6 mm). Hedyotis hamiguitanensis found at c. $1600 \mathrm{~m}$. altitude also shares similar features with $H$. schlechteri with its scabrid leaf texture, inflorescences 5-6.5 cm long, and flowers up to $7 \mathrm{~mm}$ long. However, $H$. hamiguitanensis differs from $H$. schlechteri in the lanceolate to oblanceolate leaf blades (vs. broadly ovate), obscure lateral veins (vs. prominent), planar lead margin (vs. revolute), hirsute stipules (vs. scabrid), 5-12 cm long inflorescences (vs. $5-6.5 \mathrm{~cm}$ ), and larger flowers that are 8-11 mm long (vs. 5-7 mm).

Although the flower orientation was not mentioned in the protologue descriptions of $H$. whitehea- dii and $H$. schlechteri, the type specimens of $H$. whiteheadii, E.D.Merill 5783 (US 00137449 [image!] and $H$. schlechteri, R.Schlechter 19761, (K000760468 [image!], K000760467 [image!] exhibit an upward flower orientation. Hedyotis hamiguitanensis flowers, on the other hand, are pendulous. Table 1 provides a summary of the morphological differences between $H$. hamiguitanensis, $H$. whiteheadii and $H$. schlechteri.

\section{ACKNOWLEDGEMENTS}

The authors thank the directors and curators of PNH and CAHUP for granting access to the herbarium collections, the University of Santo Tomas Research Center for the Natural and Applied Sciences and the Philippine Council for Health, Research and Development (PCHRD) for allowing P.J.R. Santor, D.D.B. Santiago, C.J.V. Mataga, E.S. Gabriel to utilize the laboratory facilities. P.J.R. Santor would like to acknowledge S.G. Zamudio, J.A. Ordas, J.M.Arshed, N.K. Alfeche, C. Banag-Moran, the local government units of Davao Oriental, the Department of Environment and Natural Resources (DENR) and the Department of Science and Technology VII for support and the necessary permits to conduct this study. 


\section{REFERENCES}

Andersson L, Rova JHE. 1999. The rps16 intron and the phylogeny of the Rubioideae (Rubiaceae). Plant Systematic Evolution. 214: 161-186.

Beentje H. 2010. The Kew plant glossary: An illustrated dictionary of plant terms. Royal Botanic Gardens, Kew, UK. p. 170.

Bremer B. 1996. Phylogenetic studies within the Rubiaceae and relationships to other families based on molecular data. Opera Botanica Belgica. 7: 33-50.

Bremer B, Manen JF. 2000. Phylogeny and classification of the subfamily Rubioideae (Rubiaceae). Plant Systematic Evolution. 225 (1-4): 43-72. https://doi. org/10.1007/BF00985458.

Groeninckx I, Dessein S, Ochoterena H, Persson C, Motley TJ, Kårehed J, Bremer B, Huysmans S, Smets E. 2009. Phylogeny of the Herbaceous Tribe Spermacoceae (Rubiaceae) Based on Plastid DNA Data. Annals of the Missouri Botanical Garden. 96(1): 109-132. https://doi.org/10.3417/2006201.

Guo X, Wang RJ, Simmons MP, But PPH, Yu J. 2013. Phylogeny of the Asian Hedyotis-Oldenlandia complex (Spermacoceae, Rubiaceae): Evidence for high levels of polyphyly and the parallel evolution of diplophragmous capsules. Molecular Phylogenetics and Evolution. 67(1): 110-122. https://doi. org/10.1016/j.ympev.2013.01.006.

Guoy M, Guindon S, Gascuel O. 2010. SeaView version 4: a multiplatform graphical user interface for sequence alignment and phylogenetic tree building. Molecular Biology and Evolution. 27(2): 221-224. https://doi. org/doi:10.1093/molbev/msp259.

IUCN Standards and Petitions Subcommittee. 2019. Guidelines for using the IUCN Red List categories and criteria Version 14. Standards and Petitions Subcommittee. [accessed 2020 December 1]. https://www.iucnredlist.org/resources/redlistguidelines.

Kårehed J, Groeninckx I, Dessein S, Motley TJ, Bremer B. 2008. The phylogenetic utility of chloroplast and nuclear DNA markers and the phylogeny of the Rubiaceae tribe Spermacoceae. Molecular Phylogenetics and Evolution 49(3): 843-866. https://doi. org/10.1016/j.ympev.2008.09.025.

Katoh K, Standley DM. 2013. MAFFT multiple sequence alignment software version 7: Improvements in performance and usability. Molecular Biology and Evolution. 30(4): 772-780. 780. https://doi.org/ doi:10.1093/molbev/mst010.

Linnaeus C. 1753. Species Plantarum. 1. Stockholm: Laurentius Salvii.
Merill ED. 1907. The Philippine plants collected by the Wilkes United States Exploring Expedition. Philipp J Sci, Section C, Botany. Manila. 2: 303.

Merrill ED, Perry LM. 1945. Plantae Papuanae Archboldianae XV. J. Arnold Arbor. 26: 1.

Miller MA, Pfeiffer, W, Schwartz T. 2010. Creating the CIPRES Science Gateway for inference of large phylogenetic trees. In Gateway Computing Environments Workshop (GCE), p. 1-8.

Neupane S, Dessein S, Wikström N, Lewis PO, Long C, Bremer B, Motley TJ. 2015. The Hedyotis-Oldenlandia complex (Rubiaceae: Spermacoceae) in Asia and the Pacific: Phylogeny revisited with new generic delimitations. Taxon. 64(2): 299-322. https://doi. org/10.12705/642.8.

Pelser PB, Barcelona JF, Nickrent DL. 2011. Co's Digital Flora of the Philippines. [accessed 2019 July 23]. http://philippineplants.org/Families/Pandanaceae. html.

Ronquist F, Teslenko M, van der Mark P, Ayres DL, Darling A, Höhna S, Larget B, Liu L, Suchard MA, Huelsenbeck JP. 2012. MrBayes 3.2: Efficient bayesian phylogenetic inference and model choice across a large model space. Systematic Biology. 61(3): 539542. https://doi.org/10.1093/sysbio/sys029.

Terrell EE, Robinson H. 2003. Survey of Asian and Pacific species of Hedyotis and Exallage (Rubiaceae) with nomenclatural notes on Hedyotis types. Taxon. 52(4): 775-782.

Wikström N, Neupane S, Kårehed J, Motley TJ, Bremer B. 2013. Phylogeny of Hedyotis L. (Rubiaceae: Spermacoceae): Redefining a complex Asian-Pacific assemblage. Taxon. 62(2): 357-374. https://doi. org/10.12705/622.2. 